\title{
E-BUSINESS MATURITY AND INFORMATION TECHNOLOGY
}

\author{
Elisabete Morais, José Adriano Pires \\ Instituto Politécnico de Bragança, Bragança, Portugal \\ beta@ipb.pt,adriano@ipb.pt \\ Ramiro Gonçalves \\ Universidade de Trás-os-Montes,Vila Real,Portugal \\ ramiro@utad.pt
}

Keywords: $\quad$ E-Business, maturity, stages of growth, Information Technology

\begin{abstract}
Maturity models describe the maturing of the use of information systems in organizations. They are a useful framework to describe an organization's current position as well as a range of possible position in the future in terms of their e-business maturity. The relationship between Information Technology (IT) and e-business maturity is examined. We used a model of e-business maturity, Stages Of Growth for e-business (SOGe) model, to put an organization in a maturity stage. In our survey we presented a set of technologies and we asked to enterprises which of them are implemented, in development, planned or inexistent. We concluded that there is a strongly correlation between IT implementation and the e-business maturity.
\end{abstract}

\section{INTRODUCTION}

Whether IT is considered in strategic terms or not, it is generally accepted that the management efforts surrounding the technology play a pivotal role in ensuring its successful use (Booth and Philip, 2005).

The primary issue with any strategic tool is the degree that its usage benefits the user. Yet, strategic tools are often employed with little concrete understanding of the advantages they engender (Stone et al., 2007). It is popular to consider that the usage of technology provides high returns, some authors suggests this is not always true (Macmillan, 1997), (Grover et al., 1998). Technologies can, in fact, have uncertain, little or no impact on profitability (O’Sullivan, 1998), calling into question how such strategic decisions are assessed (Torkzadeh and Doll, 1999) and the reassessment IT value (Tallon et al., 2000).

While IT is credited with enhancing productivity (Anandarajan et al., 2000), it remains less clear to what degree productivity from using IT is rewarding in a competitive environment since a variety of components must be used effectively to ensure quality usage. As a result, since some time that theme in IT research focuses on understanding linkages between IT and its impact on performance (Griswold, 1998). E-business IT investments have many potential uses, such as enhancing customer marketing and sales relationships or facilitating the acquisition of the input goods to production (Kleist, 2003).

Providing a linkage between some IT use and impacts on e-business maturity is the focus for the study presented in this paper.

Our purpose in this paper is to know the ebusiness maturity of the Portuguese enterprises and identifying what is the IT used by these enterprises and which is the correlation between the technology and e-business maturity.

\section{E-BUSINESS AND MATURITY}

\subsection{Definition of e-business}

The terminology involved within the field of Information Communication Technology (ICT) usage on the Internet is vast and contradictory. Two frequently used terms are e-commerce and ebusiness. Kalakota and Whinston (1996) define ecommerce as the “... buying and selling of information, products and services via computer networks". Laudon and Travel (2006) define ecommerce as the "use of the Internet and the Web to 
transact business". Others argue that e-business encompasses the entire word of internal and external electronically based activities, including ecommerce (Kalakota and Robinson, 2003). In the scope of this paper we used the definition of ebusiness given by Kalakota and Robinson (2003).

\subsection{The stages concept maturity in e- business}

The stages theory provides an insight into the way IT evolves in organizations, and offers IT management the possibility of managing this complex phenomenon (Khandelwal and Ferguson, 1999).

Nolan's stages hypothesis first appeared in the 70's, bringing with a series of debates and arguments on the validity and viability of the stages concept in Information Systems (IS). After the first model (Nolan, 1973), various models appeared.

More recently, with the emergence of the Internet and e-commerce, several stages of growth models were formulated to describe the various phases involved in moving towards greater sophistication with the respect to the use and management of Information Systems/Information Technology in the new e-commerce environment. Amongst these are the electronic commerce maturity model (KPMG, 1997); Grant's Model (Grant, 1999); the maturity model of McKay et al., (2000); the model of Earl (2000); the SOG-e Model (Prananto et al., 2001); the model of Rayport and Jaworski (2002); the model of Rao et al. (2003) and the model of Chan and Swatman (2004).

After comparing the models, we chose the SOGe Model, in order to explain the e-business maturity in the context of the Portuguese enterprises.

To compare the models we used the comparative framework to evaluate e-business stages of growth models (Morais et al., 2007).

As with all other stages of growth models, the SOGe model assumes that a normal progression is from a less mature stage to an increasing sophistication over time (Prananto et al., 2003).

\section{THE RESERCH DESIGN}

\subsection{Data Collection}

A survey technique was used to collect data.

Prior to distribution, a series of pilot tests were conducted with a group of 10 information system director enterprises from a range of businesses and a group of $5 \mathrm{PhD}$ students. After the questionnaire had been finalized, it was administered to 1000 managing directors of the biggest (according to amount of business) Portuguese enterprises. A total of 1000 presentation letters of the questionnaire were sent by post. This presentation letter and e-mail referred the website, the login and password for the survey. The presentation letters of the questionnaire were distributed in November 2007.

\subsection{Sample}

Within the cut-off date, set at 3 weeks after the survey was distributed, there were 208 returned questionnaires. Of the 208 questionnaires, 40 were eliminated from the sample, because they were incompletes. Effectively, 168 usable responses were included in the sample for further analysis, representing a good response rate at $16,8 \%$. This is well above the normal low response rate of $5-10 \%$ for a postal survey (Alreck and Settle, 1985), (Barnett, 1991).

\section{RESULTS}

\subsection{Demographics}

The sample is characterized by values on several variables that are displayed in table 1 . The respondents self-reported all the demographic values that are reported.

Table 1: The demographics for the sample.

\begin{tabular}{|c|c|c|c|c|}
\hline \multicolumn{5}{|c|}{ Function } \\
\hline Director (\%) & $\begin{array}{c}\text { General } \\
\text { Director } \\
\text { (\%) }\end{array}$ & $\begin{array}{c}\text { Administrator } \\
(\%)\end{array}$ & $\begin{array}{c}\text { Executive } \\
\text { (\%) }\end{array}$ & Other (\%) \\
\hline $50,0 \%$ & $7,3 \%$ & $5,5 \%$ & $14,6 \%$ & $22,6 \%$ \\
\hline \multicolumn{5}{|c|}{ Education Level } \\
\hline Higher ec & tion (\%) & $\begin{array}{c}\text { Post Graduation } \\
(\%)\end{array}$ & \multicolumn{2}{|c|}{ Secondary School (\%) } \\
\hline \multicolumn{2}{|c|}{$57,6 \%$} & $29,7 \%$ & \multicolumn{2}{|c|}{$12,7 \%$} \\
\hline \multicolumn{5}{|c|}{ Number of employees } \\
\hline $1-50(\%)$ & $51-250(\%)$ & $251-500(\%)$ & $\begin{array}{c}501-1000 \\
(\%)\end{array}$ & $1000+(\%)$ \\
\hline $11,9 \%$ & $28,1 \%$ & $18,8 \%$ & $23,1 \%$ & $18,1 \%$ \\
\hline \multicolumn{5}{|c|}{ Website } \\
\hline \multirow{2}{*}{\multicolumn{2}{|c|}{$\begin{array}{c}\text { Yes (\%) } \\
83 \%\end{array}$}} & & \multicolumn{2}{|c|}{ No (\%) } \\
\hline & & $83 \%$ & \multicolumn{2}{|c|}{$17 \%$} \\
\hline
\end{tabular}

Within the sample, $50 \%$ are directors, $7,3 \%$ general directors, 5,5\% administrators, $14,6 \%$ executives and $22,6 \%$ have other function in enterprise. The majority of the cases are responsible for Information Systems (IS) department. In the sample we have 
40\% with less than 250 employees, condition in Portugal to be SME. But this only happens when the amount of business is minor than 50000000 Euros and the active also minor than 43000000 Euros. Within the sample, none of them is SME. 83\% indicated the website and $17 \%$ do not indicated.

\subsection{Relationship between IT and e- business maturity}

In figure 1 we can see that almost half of the sample is between stage 5 and 6 and only 26\% are in the two first maturity stages.

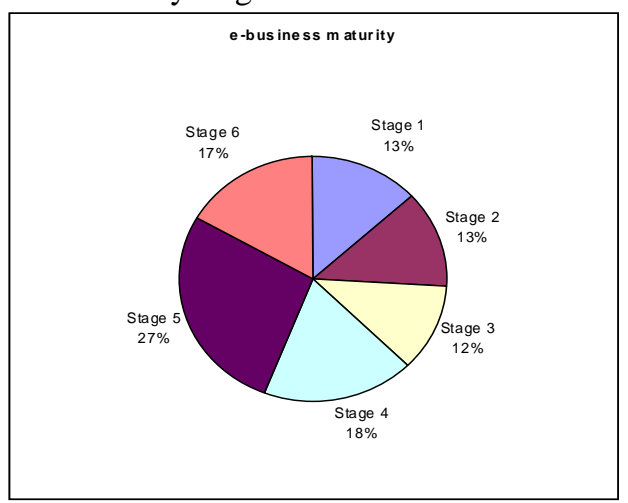

Figure 1: E-business maturity of the biggest Portuguese enterprises.

The respondents were questioned about a set of technologies: Enterprise Resource Planning (ERP), Customer Relationship Management (CRM), Supply Chain Management (SCM), Data warehouse, Business Intelligence (BI), Electronic Data Interchange (EDI), Business-to-Business (B2B), Business-to-Consumer (B2C), Business-toGovernment (B2G), Workflow, Groupware and Knowledge Management (KM). The respondents could choose one of the following options: implemented, in development, planned or inexistent. Besides these options the respondents could also add other technologies used by the companies.

In order to explore the relationship between each technology and the maturity, we used the Spearman Correlation test. Both the variables are ordinal, the maturity is an ordinal variable with values from one to six (corresponding to the stage one to six) and the IT is an ordinal variable with values from one to four (corresponding to implemented, in development, planned and inexistent, respectively). The results of the test they are shown in table 2.

Table 2: Spearman Correlation test between IT and Maturity.

\begin{tabular}{|c|c|c|}
\hline & & Maturity \\
\hline \multirow{3}{*}{ ERP } & Correlation coefficient &,$- 259(* *)$ \\
\hline & Sig & 001 \\
\hline & $\mathrm{N}$ & 164 \\
\hline \multirow{3}{*}{ CRM } & Correlation coefficient &,$- 479(* *)$ \\
\hline & Sig &, 000 \\
\hline & $\mathrm{N}$ & 158 \\
\hline \multirow{3}{*}{ SCM } & Correlation coefficient &,$- 458(* *)$ \\
\hline & Sig &, 000 \\
\hline & $\mathrm{N}$ & 157 \\
\hline \multirow{3}{*}{ DW } & Correlation coefficient &,$- 423(* *)$ \\
\hline & Sig &, 000 \\
\hline & $\mathrm{N}$ & 160 \\
\hline \multirow{3}{*}{ BI } & Correlation coefficient &,$- 438(* *)$ \\
\hline & Sig &, 000 \\
\hline & $\mathrm{N}$ & 155 \\
\hline \multirow{3}{*}{ EDI } & Correlation coefficient &,$- 381(* *)$ \\
\hline & Sig &, 000 \\
\hline & $\mathrm{N}$ & 158 \\
\hline \multirow{3}{*}{ B2B } & Correlation coefficient &,$- 667(* *)$ \\
\hline & Sig & 000 \\
\hline & $\mathrm{N}$ & 155 \\
\hline \multirow{3}{*}{ B2C } & Correlation coefficient &,$- 559(* *)$ \\
\hline & Sig & 000 \\
\hline & $\mathrm{N}$ & 148 \\
\hline \multirow{3}{*}{ B2G } & Correlation coefficient &,$- 491(* *)$ \\
\hline & Sig &, 000 \\
\hline & $\mathrm{N}$ & 146 \\
\hline \multirow{3}{*}{ Workflow } & Correlation coefficient &,$- 424(* *)$ \\
\hline & Sig &, 000 \\
\hline & $\mathrm{N}$ & 157 \\
\hline \multirow{3}{*}{ Groupware } & Correlation coefficient &,$- 420(* *)$ \\
\hline & Sig &, 000 \\
\hline & $\mathrm{N}$ & 147 \\
\hline \multirow{3}{*}{ KM } & Correlation coefficient &,$- 428(* *)$ \\
\hline & Sig &, 000 \\
\hline & $\mathrm{N}$ & 147 \\
\hline
\end{tabular}

The test results lead us to conclude that in all technologies the correlation with the maturity is significant at $1 \%$. That is, the higher the maturity stage is, the bigger is the probability of the technology being implemented, and the less the maturity stage is, the higher is the probability of the non-existence of the technology.

The strongest correlation is with B2B and the weakest is with ERP, however, all of them are significant at the 0,01 level. The maturity and the IT above referred are not independent.

We also made the correlation between all the technologies and the enterprise dimension (number of employees), and through the results of the test we concluded that the variable number of employees is not independent from the IT.

\section{CONCLUSIONS}

Understanding to what degree a strategic tool benefits the organization is a critical issue (Stone et al., 2007). Moreover, understanding to what degree a strategic tool benefits the e-business maturity is also 
a crucial matter. We cannot conclude which is the degree, but with our survey we can conclude that there is a correlation between some technologies and the maturity of the e-business, being that some have an almost perfect correlation.

In the last few years several initiatives have been taken in Portugal and, at the end of 2005, the Technological Plan was launched. This plan, included in a broader plan - the National Action Program for Growth and Jobs, 2005-2008 - is based on three main axes: knowledge, technology and innovation.

Summing up, considering all the technologies we can conclude that they are not independent from the maturity variable, nor of the dimension of the enterprise. The more employees the enterprise has and the bigger maturity stage is, the greater is the probability to have the technologies implemented. Our survey was implemented in the 1000 biggest Portuguese enterprises. It would also be interesting to apply it to SME and for activity sectors.

\section{REFERENCES}

Alreck, L., Settle, B., 1985. The survey research handbook. Irwin.

Anandarajan, M., Igbaria, M., Anakwe, U. P., 2000. Technology acceptance in the banking industry: a perspective from a less developed country. Information Technology \& People, 13 (4), 298-312.

Barnett, V., 1991. Sample survey: Principles and methods. Edward Arnold.

Booth M. E., Philip G., 2005. Information systems management: role of planning, alignment and leadership. Behaviour \& Information Technology, 24(5), 391-404.

Chan C., Swatman, P., 2004. B2B E-commerce stages of growth: the strategic imperatives. In Proceedings of the 37th Hawaii International Conference on Systems Science .Hawaii, USA, pp. 80230a.

Earl, M. J., 2000. Evolving the E-Business. Business Strategy Review, 11 (2), 33-38.

Grant S., 1999. E-Commerce for Small Businesses, Innovation Through Electronic Commerce. In Proceedings of the $2^{\text {nd }}$ International Conference. Manchester, England.

Griswold, C., 1998. Evaluating IT investments. Health Management Technology, 19, 24-26.

Grover, V., Teng, J., Fiedler, K., 1998. IS investment priorities in contemporary organizations. Communications of the ACM, 41, 40-48.

Kalakota, R., Whinston. A., 1996. Frontiers of Electronic Commerce. Addison-Wesley.

Kalakota, R., Robinson M., 2003. E-business 2.0: Roadmap for Success. $2^{\text {nd }}$ edition, Addison-Wesley.
Khandelwal, V., Ferguson, J., 1999. Critical Success Factors (CSFs) and the Growth of IT in Selected Geographic Regions. In Proceedings of 32nd Hawaii International Conference on Systems Sciences (HICSS-32), USA.

Kleist V., 2003. An Approach to Evaluating E-Business Information Systems Projects. Information Systems Frontiers, 5 (3), 249-263.

KPMJ, 1997. Electronic Commerce Research Report. London, UK.

Laudon, K., Traver C., 2006. E-commerce Business, Technology, Society. Prentice Hall.

Macmillan, H., 1997. Managing information systems: three key principles for general managers. Journal of General Management, 22, 12-23.

McKay, J., Prananto, A., Marshall, P., 2000. E-business Maturity: The SOG-e Model. In Proceedings of the $11^{\text {th }}$ Australasian Conference on Information Systems (ACIS), Australia.

Morais, E., Gonçalves, R., Pires J., 2007. Electronic Commerce Maturity: A Review of the Principal Models. In Proceedings of IADIS International Conference - E-Society 2007, Lisbon, Portugal, 3-6 July.

Nolan, R. L., 1973. Managing the Computer Resource: A Stage Hypothesis. Communications of ACM, 16 (7), 339-406.

O’Sullivan, O., 1998. Technology spending's uncertain payback. USBANKER, 108, 32-44.

Prananto, A., McKay, J., Marshall, P., 2001. Frameworks to Support E-Business Strategy. In Global CoOperation in the New Millennium, The $9^{\text {th }}$ European Conference on Information Systems. Bled, Slovenia.

Prananto, A., Marshall, P., McKay, J., 2003. Spectrum of eBusiness Maturity in Australian SMEs: A Multiple Case Studies Approach to the Applicability of the Stages Of Growth for eBusiness Model. In Proceedings of the Eleventh European Conference on Information Systems, Napoli, Italy, 16-21 June.

Rao, S., Metts, G., Monge, C., 2003. Electronic Commerce Development in Small and Medium Sized Enterprises: A Stage Model and its Implications. Business Process Management Journal, 9(1); 11-32.

Rayport, J. F., Jaworski B. J., 2002. Introduction to ECommerce. New York, McGraw-Hill.

Stone, R. W., Good, D. J., Baker-Eveleth L., 2007. The impact of information technology on individual and firm marketing performance. Behaviour and Information Technology, 26 (6), 465-482.

Tallon, P., Kraemer, K. L., Gurbaxani, V., 2000. Executives' perceptions of the business value of information technology: a process oriented approach. Journal of Management Information Systems, 16(4), 145-173.

Torkzadeh, G., Doll, W.J., 1999. The development of a tool for measuring the perceived impact of information technology on work. Omega. 27, 297-300. 